\title{
SOCIOECONOMIC ANALYSIS FOR HIGH CAPACITY TRANSPORTATION - THE CASE OF CURITIBA'S SUBWAY
}

\author{
Luciana Costa Brizon $^{1 *}$; Milena Santana Borges ${ }^{2}$ e Romulo Dante Orrico Filho ${ }^{3}$ \\ 1 Tecnotan Engenheiros Consultores, 30112-020, Belo Horizonte-MG, Brasil \\ 2 Oficina Consultores, 04128-000, São Paulo-SP, Brasil \\ 3 Universidade Federal do Rio de Janeiro, 21941-914, Rio de Janeiro-RJ, Brasil \\ lucostta@hotmail.com
}

Submitted at 31/08/2017 and accepted at 05/12/2017

\begin{abstract}
Brazilian cities face daily difficulties caused by congestion, with significant losses in quality of life for the population There are several problems that lead to this state of degradation. Among them, the lack of capacity of the various modes of public transportation to offer seats that meet the demand of passengers at peak hours stands out regarding passenger urban transport systems. This article proposes to carry out a socioeconomic analysis of the gains brought by the reduction of congestion in terms of lower pollution, travel times, accidents and fuel consumption with the introduction of a higher capacity mode using a less polluting energy source. Also, and most
\end{abstract}

importantly, it aims to analyze the possibility of financing subway implantation and expansion projects through the economy in the consumption of petroleum fuels. This would be possible with the substitution of the diesel consumed by the road transportation mode with the consumption of electricity by the subway mode. This evaluation was applied to the subway implementation project for Curitiba. The results show that the socioeconomic gains can finance a large part of the development and present significant gains in quality of life, reducing the levels of air pollutants, traffic accidents and displacement times for the population of Curitiba.

KEYWORDS: mobility; metrorail system; socioeconomic analysis.

\section{AVALIAÇÃO SOCIOECONÔMICA PARA TRANSPORTES DE ALTA CAPACIDADE - ESTUDO DE CASO DO METRÔ DE CURITIBA}

\begin{abstract}
RESUMO
Cidades brasileiras enfrentam diariamente dificuldades ocasionadas pelos congestionamentos, com perdas significativas na qualidade de vida da população. São vários os problemas que conduzem a esse estado de degradação. Entre eles, destaca-se, nos sistemas de transporte urbano de passageiros, a falta de capacidade dos diversos modos do transporte público em ofertar lugares de forma compatível com a demanda. Este artigo propõe realizar uma análise socioeconômica dos ganhos com a redução dos congestionamentos, da poluição, dos tempos de viagens, dos acidentes e do consumo de combustível, a partir da introdução de um modo de maior capacidade e consumidor de uma forma de energia
\end{abstract}

menos poluente. Além disso, e principalmente, pretende analisar a possibilidade de se viabilizar o financiamento dos projetos metroferroviários por meio da economia do consumo de combustíveis derivados do petróleo. Essa viabilização se daria com a substituição do diesel consumido no rodoviário pelo consumo de eletricidade no metroferroviário. A avaliação foi aplicada para o projeto do metrô em Curitiba. Os resultados mostram que os ganhos socioeconômicos podem financiar grande parte do empreendimento e apresentar ganhos na qualidade de vida, com a redução dos níveis de poluentes do ar, dos acidentes de trânsito e dos tempos de deslocamento dos habitantes de Curitiba.

PALAVRAS-CHAVE: mobilidade; sistema metroferroviário; avaliação socioeconômica. 


\section{INTRODUCTION}

High-quality public transportation services are a key element to improve urban mobility in large cities. In this context, it is important to notice that an efficient public transport can bring significant gains for the population in terms of quality of life (Aljoufie et al., 2016), reducing, for example, environmental pollution levels and travel times. It is also relevant regarding the economic development of cities and fuel consumption savings.

In Brazil, urban passenger transportation was responsible for the consumption of 13.6 million toe (tonne of oil equivalent) in 2014 (ANTP, 2017), which corresponds to approximately $5.5 \%$ of the total amount of energy consumed in the country (petroleum and oil products, biofuels and electric power). According to Marins and Romero (2012), this scenario presents a high level of power consumption considering its restricted scope (transporting people in urban areas). This fact is strongly related to the lack of proper urban planning and to the amount and extension of people's displacements in urban areas, as well as the intensive use of certain transport modes rather than others.

Brazil's Public Transportation National Association (ANTP) studied the evolution of mobility in Brazilian cities from 2003 to 2014 and pointed out the increasing problems in urban passenger transportation systems in big and medium cities, triggered largely by heavy motorization (ANTP, 2017). This issue reflects very negatively on the population's quality of life, as every single day there are more cars on the streets, increasing traffic jams. Therefore, there is a higher level of pollution, as well as a significant increase in travel times and fuel consumption, both in public and private transports.

Urban mobility is a growing issue worldwide, especially in Brazil. Population densification in large cities leads to great economy of scale but also to some problems as the trend of increasing average travel times for residents of suburban areas (VIANNA; MACHADO, 2017). Studies like Gomide (2003), Vianna e Young (2015), Aragão et al.(2016) e Paget-Seekins e Walters (2016), Lin e Benjamin (2017) show how mobility influences people's life, whether concerning its economic (loss of time and logistics barriers), personal (stress and body aches), social (triggered by mobility inequalities) or environmental effects (air pollution and excessive use of fossil fuels).

Sustainability in large urban areas is strongly related to transportation as far as it can cause substantial impact in quality of life (UN-HABITAT, 2013), either by its role in urban development or because it can generate negative externalities such as high power consumption, traffic accidents or greenhouse gas emission (SOUZA, 2015). In developing countries these effects tend to be even more severe, especially in poorer segments of society (UN-HABITAT, 2013).

The main objective of this study is to evaluate how socioeconomic gains due to the implementation of subway infrastructure can contribute to the their self-financing and at what level the efficiency of these rail systems can render the city more sustainable both from the environmental and the socioeconomic points of view.

Firstly, a socioeconomic analysis of the gains concerning pollution, travel times, traffic accidents and fuel consumption reductions was carried out. Then, based on this analysis, the resulting savings were measured, as well as their capacity to make rail system implantation projects viable. Moreover, it was considered that by switching from road to rail systems the decreased consumption of diesel fuel (on urban passenger transportation) could itself contribute to finance subway projects. 


\section{BIBLIOGRAPHIC REVIEW}

This section presents a theoretical review of the following subjects: urban diseconomies caused by traffic jams (travel time, traffic accidents, pollution emission and fuel consumption); BRT systems; subway systems; and the matter of diesel oil market. This review provided the basis for conceiving a socioeconomic evaluation of Curitiba's subway project.

The section is laid out in 3 parts. The first one presents the methodological concepts, as well as monetarization and urban diseconomies. It is worth pointing out that the calculation methodology displayed was used to evaluate Curitiba's subway studies. The second part presents a review on urban passenger transportation and diesel oil consumption. Lastly, the third subsection presents a comparative analysis between BRT and subway transport systems, their advantages and disadvantages.

\subsection{Urban Diseconomies}

\section{- Time Savings}

Time can be considered one of the main delimiters of human activities (VASCONCELOS, 2000). According to Silva (2008), it can be explained as something far beyond its extent on physics or mathematics. The time variable is here considered an element that attaches a parameter to transportation modes; that is, travel time is a decision criterion on choosing what mode will be used.

For Gomide (2003), travel overtime could be used with other paying activities or even to satisfy basic needs such as leisure. Moreover, long time trips can cause productivity decline on urban workers.

Traditionally, in transportation planning time is valued indirectly by considering people's income. It is assumed that lost travel time can be valued according to one's salary in the sense of lost time for economic production. It is also perceived that people value their time based on personal characteristics (like income level and age) and specific features of displacement (like time inside the transport, waiting and walking times) (VASCONCELLOS; LIMA, 1998). Thus, work trips usually have productive value for the employees and society, and its valuation is based on the income per time unit (usually per hour) or income rate expressed in \$/hour, adding employer's extra costs.

Different studies by Kenneth Small (1992 and 2006) mention that in developed countries the estimations on time value for work trips range from 20 to $100 \%$ of gross wage. Recently, the author got to the conclusion that a reasonable average value for travel time on work trips is around $50 \%$ of gross wage.

In a joint study carried out in 1998 by Brazil's Public Transportation National Association (ANTP) and the Research Institute on Applied Economics (IPEA), in order to evaluate lost time costs in traffic jams in Brazilian cities, the most widely used methodology in economic viability studies by that time was applied, according to the Urban Transportation Project Analysis Manual (EBTU, 1987). The average income of each city was used, expressed in terms of minimum salaries, regardless of those specific ones from bus or car users. The following formula was used to calculate the hour value:

$$
\text { CT }(R S M \times E S \times F A \times H P / N H) C T \quad(R S M \times E S \times F A \times H P / N R)
$$

Where: $(C T=$ hour value $(R \$ /$ hour $) ; R S M=$ average income of city inhabitants $(E A P)$; ES = social charges $(95.02 \%)$; $F A=0.3$ (possibility of alternative use in terms of useful amount of time); $H P=$ percentage of productive time usage $(\%$ work trips + \%home-work trips *0.75) - if not available, it assumes the value of $0.5 ; \mathrm{NH}=$ number of working hours per month = 168 hours.) 
According to Pinheiro, Fontes and Azevedo (2015), the conditions for mobility have been declining over the last decades, with the increasing home-work average travel times. One of the reasons for that is the growing number of vehicles in the metropolises. Hence, mobility issues become worse and worse as people do not internalize the consequences of their transport options over other people's travel times, resulting in bigger traffic jams.

\section{- Pollution Reduction}

The atmosphere is a dynamic system subject to changes on its characteristics both in local and/or global levels. Usually, these changes occur due to natural facts, like volcanic eruptions or wildfires. However, it is currently a common understanding that human actions can modify atmospheric composition, weather on the surroundings of large urban areas or even at a global level. Such alterations can be severe for the planet climate change, especially in the long-term (VIEIRA and SILVA, 2017).

Atmospheric pollution is considered one of the most critical issues in large urban agglomerations. It comes from the emission of hundreds of toxic gases and particulate matter generated from stationary and mobile sources, which, retained in the air, can cause several health problems (LANDMANN; RIBEIRO; DEAK, 2007).

The transport sector is pointed out as one of the greatest triggers of pollution in big metropolises, particularly in developing countries. In Brazil, during the 1960s and 1970s, air pollution was mostly originated from industrial sources. Yet this panorama has changed and transportation has become the major source of pollutant emissions. The reason for that shift is that industries started to be required to control their emissions and simultaneously there was a steep increase in the circulating car fleet. To illustrate the control over the industry and other activities, in May of 1976 the State of São Paulo promulgated Law n.997, describing the implementation of control policies that did not exist by then (RIBEIRO; ASSUNÇÃO, 2001).

With the increasing global concern with the environment, particularly after the United Nations Conference on Environment and Development in 1992, environmental benefits analyses have gained greater importance. For instance, nowadays it is recommended by financial agents (like the World Bank and the Inter-American Development Bank) that environmental costs and benefits on viability analysis projects are indicated and explicitly defined in monetary terms (LANDMANN; RIBEIRO; DEAK, 2007). In Brazil, the transport sector was responsible for $36 \%$ of $\mathrm{CO}_{2}$ emissions in 2012, a total of 212.2 million tons of $\mathrm{CO} 2,93 \%$ of which were produced by road transport. Actually, road transport CO2 emissions grew between 1990 and 2005 (MCTIC, 2013; MMA, 2013).

The resulting effects of these pollutant emissions led to a major public health problem in Brazil, including extensive welfare and health damage on the population of large urban centers (EPA, 2013). Among the key pollutants that directly affect human health, the following are particularly worth highlighting: Carbon monoxide (CO), Sulphur dioxide (SO2), toxic organic substances, particulate matter (PM) and those arising from photochemical smog, such as Nitrogen oxide (NOx) and volatile organic compounds (VOC) (GUARIERO et al., 2011).

Due to the lack of specific studies on the parameters used for local conditions, European and American values for damage costs from vehicle emissions calculated for urban areas are usually adopted on the viability analysis of transportation projects in Brazil, considering some necessary adjustments. The reference approach for Brazilian projects is presented on a widely publicized release among transportation professionals, developed jointly by ANTP and IPEA (1998). This methodology will be presented in the following section and will be used to calculate pollutant emission costs. 
The emission coefficients for motor vehicles differ widely according to fuel and vehicle conditions. For diesel buses, four equations were obtained, one for each of the following pollutants:

$$
\begin{gathered}
H C(\mathrm{~g} / \mathrm{kml})=14,14-3,67 \ln V-\text { Hydrocarbons }(2) \\
C O(\mathrm{~g} / \mathrm{km})=43,34-8,98 \ln V-\text { Carbon Monoxide }(3) \\
\operatorname{NOx}(\mathrm{g} / \mathrm{km})=37,21-6,46 \ln V-\text { Nitrogen Oxide }(4) \\
\text { Particulados }(\mathrm{g} / \mathrm{km})=1,74-0,32 \ln V-\text { Particulate Matter }(5)
\end{gathered}
$$

It is worth underlining that these equations work for speeds up to $45 \mathrm{~km} / \mathrm{h}$. In order to get a proxy on the costs due to pollution in Brazil, information from two specific studies was considered: a World Bank study on Low Carbon for Brazil (2010), which presents more recent values about pollutant emissions in the country, and another one carried out by CETESB (2009), which was used for updating those values according to the researched emission parameters based on the experiment results for vehicles' approval regarding pollutant emissions.

The original values of these expressions (2, 3, 4 and 5) are expressed in US $\$ / \mathrm{kg}$ of emissions and they were converted into Reals $(\mathrm{R} \$)$, considering the dollar exchange rate on February of 2017. Thus, the following final values were adopted:

$$
\begin{gathered}
C O=R \$ 0,19 / \mathrm{kg}(6) \\
H C=R \$ 1,14 / \mathrm{kg}(7) \\
\text { NOx }=R \$ 1,12 / \mathrm{kg}(8) \\
\text { Partículas }=R \$ 0,91 / \mathrm{kg}(9)
\end{gathered}
$$

\section{- Accidents Reduction}

There are several definitions of traffic accidents on the literature. For Brandão (2006) and Ferraz, Raia Jr. and Bezerra (2008), a traffic accident can be seen as an unintentional event that involves one or more vehicles (motorized or not) circulating on a roadway and that results in some sort of damage, whether material or injuries.

According to Vasconcellos and Lima (1998), calculating accident costs is a difficult task as a life lost in a car accident cannot be valued or mathematically expressed. With that in mind, some indirect measures are typically adopted on studies about accidents; they are grounded on the life insurance premium people pay for. This approach is justified based on the fact that, if people pay for having this benefit (even not desiring it), this is the value they are implicitly giving for their lives. Nonetheless, this argument is limited once there is nothing indicating that this prize is all a person looks forward to receiving as compensation.

The procedure adopted for calculating this kind of benefit takes into consideration specific accident costs for each mode of transportation. The annual benefits are then obtained by the product of these costs by the difference of the total number of passengers per kilometer, contemplating both situations, with and without the project implementation, for each transport mode and every modelling horizon analyzed. by:

Thus, the overall mathematical formulation for each transportation mode considered is given

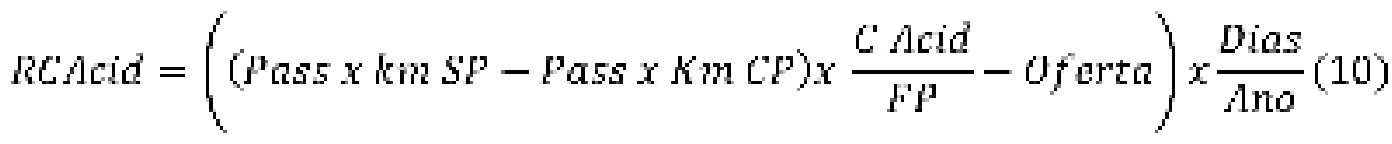


Where: $($ RCAcid $=$ Accident Cost Reductions; Pass $x$ km SP $=$ Total number of passengers per kilometer at peak hours on the scenario without project implementation; Pass $x \mathrm{~km} \mathrm{CP}=$ Total number of passengers per kilometer at peak hours on the scenario with the implemented project; FP = Peak Factor related to demand; $C$ Acid $=$ Unitary costs of accidents, specifically for buses in Brazilian transportation systems; Days/Year = Total number of equivalent days in a year.)

\section{- Fuel Consumption Reduction}

According to Vasconcellos (2006), although power use already includes fuel consumption, it is relevant to dissociate them for practical purposes when analyzing traffic and transport conditions. Therefore, the following analysis applies to gasoline and diesel consumption, which correspond to $77.5 \%$ of the total energy expenditure on transportation in Brazil.

Fuel consumption is potentially and inversely proportional to running speed; in other words, it increases a lot when speed decreases. According to an IPEA and ANTP (1998) study, both fuel consumption and pollutant emissions are directly related to speed variation.

Research developed by national and international institutions allowed the definition of some functions to be applied to each city, considering its particular situation. Equation 11 below shows the relation between diesel use and speed.

$$
c=0,44428+0,00008 V^{2}+\frac{1,37911}{v}+0,00107 \operatorname{corr}(11)
$$

Where: $V=\operatorname{speed}(\mathrm{km} / \mathrm{h})$, carr $=$ load $($ sitting + standing $)$ and $C=$ diesel consumption $(l / k m)$

Mattos (2011) states that fuel consumption efficiency varies according to the technology adopted on a BRT implementation project. For instance, in TransMilenio (Bogotá, Colombia), buses were considered to have a 160-passenger capacity. Moreover, fuel consumption efficiency presumed for it was $0.6 \mathrm{~L} / \mathrm{km}$ (CQNUMC, 2004). Hence, when the specific fuel consumption of buses and their annual covered distance are known, it is possible to estimate diesel costs for the project using the following equations:

$$
\begin{gathered}
\text { Dist. Total }(\mathrm{km})=\frac{\text { Passogeiros anuais BRT }}{\operatorname{IPK}\left(\frac{\text { passageiro }}{\mathrm{km}}\right)}(12) \\
\text { Cons.BRT }(\mathrm{l})=\text { Cons. Esp BRT }\left(\frac{L}{\mathrm{~km}}\right) \text { X Dist. Totol BRT }(\mathrm{km})(13)
\end{gathered}
$$

Using these equations (12 and 13), it is plausible to find diesel oil consumption and, multiplying it by the diesel price in the study area, the monetary savings due to project implementation can be estimated.

Based on the above, it becomes clear that there is a need for frequent evaluations about economic costs inherent to urban mobility conditions, which should work as planning and public policy design instruments. The fact is that cost-benefit analyses comparing different urban mobility projects (widely necessary but seldom carried out) sometimes run into the difficulty of quantifying and monetarizing the costs incurred by society due to traffic congestions. Indeed, this only reinforces that a focused study on this issue is mandatory. Measuring these costs also enables the evaluation of the benefits brought by solving the problem, since cost estimations serve as warnings and justify heavy investments in the sector as well (PINHEIRO; FONTES; AZEVEDO, 2015). 


\subsection{2 Transports and Diesel Consumption}

The historical milestone of the choice for road transport in Brazil was the economic development project adopted during Juscelino Kubitschek's government (1956-1961), which promoted a new industrialization stage in the country essentially based on car factories. Due to the increase in automobile production, the construction and upgrade of roads became mandatory. Furthermore, with the progressive increase of the vehicle fleet and the number of trips, the consumption of oil derivatives also grew rapidly over the years (LEITE, 1997).

When analyzing the transportation sector and fuel consumption, it is important to notice its perspective regarding energy consumption and economic variables (DARGAY; GATELY, 2007). According to the Ministry of Mines and Energy (2009), the proportion of petroleum and derivatives within Brazilian domestic energy supply increased from $34 \%$ in the 1970 s to $46 \%$ in 2000 , but it is expected to go down to $31 \%$ by 2030 . In parallel, the energy demand structure has radically changed, from an eminently rural country, with low participation of the transport sector, to an urban and developed economy.

The better fuel productivity efficiency is and the lower its prices and exports are, the better will the transportation sector's performance be and, consequently, the national economic behavior, according to Geller (2003). This analysis is supported by considering the extent of liquid fuels use in transportation proportionally to all petroleum derivatives in Brazil. In 2000, this sector was responsible for $75 \%$ of Brazilian oil consumption, which is not expected to change by 2030 as the trend for this year, according to the Ministry of Mines and Energy (2009), is that $77 \%$ of all liquid fuels demand will be focused on transportation.

The 2008 edition of the International Energy Agency's (IEA) Key World Energy Statistics shows a comparison over the years of 1973 and 2006. Over these 33 years, world fuel consumption increased $73 \%$ (from 4,672 to 8,084 million tep), and the transportation sector remained the main oil consumer in volume, with $60.5 \%$ of the total in 2006).

Thus, it is evident that energy efficiency in the transportation sector is also strategically important in the context of energy planning (DIAS; BALESTIENEI; MATTOS, 2005). According to the National Energy Plan (PNE 2030), in 2004 the sector was responsible for $61 \%$ of all national liquid fuel demand and for $78 \%$ of diesel consumption.

Furthermore, according to a study of 2009 made by the National Association of Urban Transportation Companies (NTU) in Brazil, the transportation industry is responsible for 52\% of all fossil energy consumed in the country. Also, when comparing the different transportation modes, it can be seen that the road transportation sector absorbs $92 \%$ of the energy, which means that railways, waterways and air transportation sectors have a minimal role on energy consumption. Additionally, according to the Ministry of Mines and Energy, the transportation industry accounts for more than half of all oil derivatives and natural gas consumed in Brazil, of which road transportation represents $90 \%$.

Nevertheless, Ribeiro (2002) reports it is important to consider that, in order to compare energy efficiency among the different transportation modes, not only fuel consumption should be considered but also some other elements such as: equipment used by each mode, local technical conditions and executed operational procedures.

Brazil has reached its self-sufficiency in petroleum barrels; that is, the volume of petroleum produced in the country equals or surpasses its consumption. However, most of it is heavy petroleum, which is good for the production of gasoline and some other derivatives but not for diesel production, forcing the country to import light oil or even already refined oil derivates. Thus, any project that aims at oil economy is of huge interest. 


\subsection{Comparative Analysis of Transportation Modes}

\section{- BRT Systems}

BRTs are medium to high capacity public transportation systems based on exclusive corridors for bus circulation that provide fast and comfortable transportation with a high cost to benefit relation. In order to achieve high performance, top quality of service and better experience for the users, there are five essential characteristics that, combined, define what a BRT is. They are: dedicated infrastructure for exclusive bus flow; bus lanes alignment, especially on the central traffic island; fare collection outside the bus; level boarding; and priority of way on intersections (ITDP, 2016).

The transportation capacity of BRT systems can reach 42 thousand passengers per hour (MANUAL DE BRT, 2009) if there are 2 lanes for circulation and overtaking at stations. Besides, if there are some fast lanes, they can support great service flexibility, allowing, for example, express and semi-express ones. Thus, it is ideal that BRT operates on lanes without level crossings as this leads to high operating speed. If it is not possible, depending on the service's frequency, a potential solution can be to give priority through traffic lights on intersections, which costs between 15 and 20 million US\$/km (IPPUC, 2009) or between 10 and 15 million US\$/km (ITDP, 2009).

Table 1 - BRT Advantages and Disadvantages - Applied to Curitiba's System

\begin{tabular}{|l|l|}
\hline \multicolumn{1}{|c|}{ BRT Advantages } & \multicolumn{1}{|c|}{ BRT Disadvantages } \\
\hline $\begin{array}{l}\text { On peak hours the system can transport over 18,000 } \\
\text { passengers/hour/direction }\left(6 \mathrm{pass} / \mathrm{m}^{2}\right) ;\end{array}$ & $\begin{array}{l}\text { Environmental impact: diesel engine buses lead to } \\
\text { particulate and organic compound emissions; }\end{array}$ \\
\hline $\begin{array}{l}\text { It is an intermediate solution between the current express } \\
\text { system and a high capacity mode; }\end{array}$ & $\begin{array}{l}\text { It tends to degrade the surroundings and affects } \\
\text { commerce along the corridor; }\end{array}$ \\
\hline Low implementation cost; & Little guarantee on passengers' safety; \\
\hline Maximum commercial speed of $25 \mathrm{~km} / \mathrm{h} ;$ & Level operation, reducing speed; \\
\hline Short time intervals between vehicles; & Interdependency with other systems; \\
\hline Higher capacity vehicles, reducing pollutant emissions. & It is affected by adverse weather conditions (rain). \\
\hline
\end{tabular}
Source: IPPUC (2009)

Table 1 above shows that Curitiba's BRT system presents several operational advantages, such as: $25 \mathrm{~km} / \mathrm{h}$ commercial speed (IPPUC, 2009), short intervals between vehicles and lower implementation cost per kilometer, comparing to other high capacity modes. Nonetheless, some negative aspects can also be observed: pollutant emission due to diesel engine buses, level operation which can lead to traffic accidents, and the fact that it is affected by adverse weather conditions such as rains.

\section{- Light Rail (LR)}

Light Rail (LR) is a transportation system suitable for offering an intermediate number of seats compared to buses and classic subway, and it does not need a completely dedicated lane. However, depending on the road segregation level and the adopted technology, it can satisfy a demand of 15,000 to $25,000 \mathrm{pass} / \mathrm{h} /$ direction. Thereby, it constitutes a good alternative for medium capacity transportation. The implementation cost of an LR is around 15 to 45 million US\$/km (ITDP, 2009).

Table 2 - LR Advantages and Disadvantages

\begin{tabular}{|l|l|}
\hline \multicolumn{1}{|c|}{ LR Advantages } & \multicolumn{1}{c|}{ LR Disadvantages } \\
\hline $\begin{array}{l}\text { Little space needed for implementation, urban } \\
\text { regeneration }\end{array}$ & It is not flexible for circulation outside the corridor \\
\hline Low noise level and non-pollutant & Rolling stock's high cost \\
\hline It can be easily integrated to the bus system & Operation/maintenance needs proper infrastructure \\
\hline \multicolumn{2}{|c|}{ Source: Made by the authors based on IPPUC (2009), CBTU (2015) and VLT Carioca (2017) }
\end{tabular}


Table 2 shows that LR systems constitute low-pollution technologies, promote the regeneration of neighboring areas and are easily integrated to other transportation modes. On the other hand, their implementation cost is high when compared to the BRT. Moreover, a maintenance and repair plant for the whole system is necessary (including track and light system operation).

\section{- Subway}

The technical definitions that are part of a subway project are highly complex and arise not only from the system's specific requirements but also from matters like land use, environment preservation and historical heritage.

There are light and heavy subways. Although both are considered electric rail transportation modes that can satisfy higher demands than those of BRTs or LRs, light subways have a lower capacity than heavy ones. Light subways can satisfy demands of 30,000 to 40,000 pass/h/direction and cost between 30 and 40 million US\$/km to implement (CBTU, 2012).

On the other hand, heavy subway systems can transport between 40,000 and 80,000 pass/h/direction (CBTU, 2012) and have high demand at peak hours, usually from the neighborhoods headed downtown in the morning and in the opposite direction in the afternoon.

Table 3 - Subways Advantages and Disadvantages - Considering Curitiba's Case

\begin{tabular}{|l|l|}
\hline \multicolumn{1}{|c|}{ Subway Advantages } & \multicolumn{1}{c|}{ Subway Disadvantages } \\
\hline Environmental gains & High implementation costs \\
\hline Higher safety of general traffic & Slow implementation \\
\hline Real estate valuation on the surroundings & High maintenance costs \\
\hline Increased demand, attracting car users & An integrated network is necessary for optimum performance \\
\hline Significant travel time reduction & Fixed itineraries, which can imply some interchange \\
\hline High frequency operation with regular intervals & Operation/maintenance needs proper infrastructure \\
\hline \multicolumn{2}{|c|}{ Source: Made by the authors based on BERTOLINI and SPIT (2007), METRÔ RIO (2016) and ANTP (2016) }
\end{tabular}

Table 3 shows that there are some positive features of subway systems that can be highlighted: travel time decrease due to regular operation and high frequencies; and reductions in pollutant emission and traffic accidents. On the other hand, there are some negative aspects too, mainly the high implementation cost per kilometer, the need for an integrated transportation network and the greater implantation time comparing to other high capacity transportation modes.

\section{- Comparative Analysis of Transportation Modes}

This section presents some tables comparing the transportation modes mentioned above (in terms of carrying capacity, implementation timeline as well as cost, speed and access times).

Table 4 - Capacity Per Transportation Mode

\begin{tabular}{|c|c|c|c|c|c|c|c|}
\hline 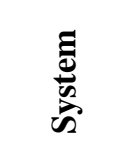 & Vehicle Type & $\begin{array}{c}\text { Structure } \\
\text { Type }\end{array}$ & Station Type & 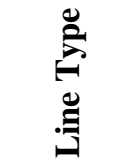 & 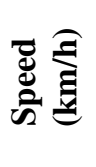 & 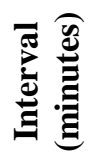 & 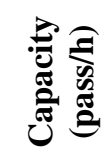 \\
\hline Subway & 8-car Train & Segregated(1) & WO / overtaking & Local & 40 & 1.5 & 96,000 \\
\hline LR & 4-car Train & Segregated(1) & WO / overtaking & Local & 20 & 3.0 & 20,000 \\
\hline BRT & Bi-articulated Bus & Exclusive(2) & WO / overtaking & Local & 20 & 1.0 & 16,200 \\
\hline BRT & Bi-articulated Bus & Exclusive(2) & W / overtaking & Express & 35 & 0.5 & 32,400 \\
\hline BRT & Bi-articulated Bus & Exclusive(2) & W / overtaking & Mixed & 27.5 & 0.3 & 48,600 \\
\hline
\end{tabular}

Source: NTU (2009)

Notes: (1) Underground / Elevated - without traffic interference

(2) Leveled track with 7.0 meters of width, 14.0 meters of length at stations where overtaking is possible 
Table 5 - Construction Periods and Implementation Costs

\begin{tabular}{|c|c|c|c|c|c|c|}
\hline \multirow{2}{*}{ Stages } & \multicolumn{2}{|c|}{ Subway } & \multicolumn{2}{c|}{ LR } & \multicolumn{2}{c|}{ BRT } \\
\cline { 2 - 7 } & $\begin{array}{c}\text { Period } \\
\text { (years) }\end{array}$ & $\begin{array}{c}\text { Cost } \\
\text { (R\$ million) }\end{array}$ & $\begin{array}{c}\text { Period } \\
\text { (years) }\end{array}$ & $\begin{array}{c}\text { Cost } \\
\text { (R\$ million) }\end{array}$ & $\begin{array}{c}\text { Period } \\
\text { (years) }\end{array}$ & $\begin{array}{c}\text { Cost } \\
\text { (R\$ million) }\end{array}$ \\
\hline Basic Project & 1 & 4.5 & 1 & 1.5 & 0.5 & 0.3 \\
\hline Funding & 2 & 0.5 & 2 & 0.5 & 0.5 & 0.2 \\
\hline Executive Project & 1 & 5.0 & 1 & 2.0 & 0.5 & 0.5 \\
\hline Implantation & 5 & $2,000.0$ & 2 & 400.0 & 1 & 110.0 \\
\hline Total & $\mathbf{9}$ & $\mathbf{2 , 0 1 0 . 0}$ & $\mathbf{5}$ & $\mathbf{4 0 4 . 0}$ & $\mathbf{2 . 5}$ & $\mathbf{1 1 1 . 0}$ \\
\hline
\end{tabular}

Source: NTU (2009)

Note: As an example, for the construction of a corridor with $10.0 \mathrm{~km}$ for 150 thousand passengers/day Costs per km: Subway $=\mathrm{R} \$ 201.0$ million $/ \mathrm{LR}=\mathrm{R} \$ 40.4$ million $/ \mathrm{BRT}=\mathrm{R} \$ 11.1$ million.

The tables above make it clear that no transportation mode can be fully regarded the best or the worst. The point is to choose the appropriate mode for each corridor, considering passengers demand, traffic conditions and integration with all the other urban transportation services. It is also worth pointing out that for any of these modes to achieve a good performance the integration of all services is mandatory.

\section{MATTERS AND METHODS}

The goal of this section is to present the methodology adopted by IPPUC to study the potential demand of Curitiba's Subway (Blue Line - Santa Cândida/CIC Sul).

IPPUC's investigation was based on historical data from URBS (Urbanização de Curitiba S.A.) and some documents related to urban mobility produced by IPPUC, among which the following are worth highlighting: High Capacity Passenger Transportation System Study (STAC, 2000); Curitiba in Data (IPPUC, 2008); Drop-on/Drop-off Survey (IPPUC, 2009); and the Research on Willingness to Change Mode (IPPUC/ICI, 2009).

The following demands were considered: from the lines already in service on the corridor; from the direct lines on mixed traffic; from the integrated lines (these are the RIT, Portuguese acronym for Integrated Transportation Network, without do not perform interchange on north/south axis terminals, and which will be incorporated into the overall system); and from the non-integrated lines (those that are still not part of the RIT but are managed by URBS and can be merged with the system).

The survey carried out by URBS in March 2009 computed all boardings on the express corridor, per direction, during the period from 6:00 a.m. to 12:00 a.m. in the north/south axis. As the system operates 24 hours a day, it was necessary to perform a demand expansion, which was done by considering boarding percentages on the survey period (6:00 a.m. to 12:00 a.m.) regarding the 24-hour period, as shown on the tables below.

Table 6 - Alight Expansion in North/South and South/North Directions

\begin{tabular}{|c|c|c|c|c|c|c|}
\hline \multirow{2}{*}{ Dados } & \multicolumn{3}{|c|}{ North/South Axis } & \multicolumn{3}{c|}{ South/North Axis } \\
\cline { 2 - 7 } & $\begin{array}{c}\text { Daily } \\
\text { Demand } \\
\text { (URBS) }\end{array}$ & $\begin{array}{c}\text { Survey's } \\
\text { projected } \\
\text { value }\end{array}$ & $\begin{array}{c}\text { Difference } \\
(\%)\end{array}$ & $\begin{array}{c}\text { Daily } \\
\text { Demand } \\
\text { (URBS) }\end{array}$ & $\begin{array}{c}\text { Survey's } \\
\text { projected } \\
\text { value }\end{array}$ & $\begin{array}{c}\text { Difference } \\
(\%)\end{array}$ \\
\hline Boarding & 135,002 & 132,813 & 1.62 & 155,209 & 148,040 & 4.62 \\
\hline Alighting & \multicolumn{3}{|c|}{ Source: IPPUC 2009 } & 142,916 & 7.92 \\
\hline
\end{tabular}

From the 24-hour URBS drop-on/drop-off survey, the most significant peak and valley hours were considered and, knowing the demand percentages per direction, a 259,900 pass/day demand was estimated for the north/south axis and 304,064 pass/day for the south/north axis. 
Demand was forecast based on a research on people's willingness to switch mode conducted by IPPUC/ICI (2008). This survey took place in the neighborhoods within the area of interest on the north/south axis. Based on that, it was estimated that $25.8 \%$ of the people are willing to switch from car to public transportation if a more comfortable and reliable mode is implemented. Population growth rates projected by IPPUC until the year 2020 were also applied, and, for the period between 2020 to 2044, the same rate estimated for 2020 was adopted.

Based on URBS's boarding and alighting survey and IPPUC's on/off passenger counts and research on willingness to switch modes - and considering the population growth rate estimated for Curitiba - it was possible to forecast the demands as of the city's subway implementation project lifetime. Therefore, a 580,000 passengers/day demand was estimated for the project outset and $1,000,000$ passengers/day as of the system's full operation. These forecasts will be used for the project socioeconomic analysis.

From this demand data, both socioeconomic and fuel savings analyses will be carried out considering Curitiba's subway implementation. The socioeconomic analysis will be presented on the next section. For monetary calculations of externalities and fuel, accidents and pollution costs, the methodology described on the bibliographic references section was adopted.

Additionally, the method used for calculating fuel savings, in terms of number of barrels of crude oil due to the change in technology used, considered the fuel (in liters of diesel) that the BRT system would consume in 30 years (that is the subway project lifetime). According to Schaeffer (2004), diesel represents $36.4 \%$ of a barrel, based on the percentage of oil extraction and refining in the market Brazilian consumption.

Considering this percentage (diesel), the number of barrels of crude oil that would be saved over the project lifetime was calculated. Subsequently, by multiplying it by the international barrel price, the overall economy was estimated. This monetary value could be reverted to subway funding.

\section{RESULTS AND ANALYSIS}

An economic evaluation qualifies and quantifies urban diseconomies. In order to measure these diseconomies, it is necessary to calculate the expenses that could be cut due to the adoption of a rail system. In the case of Curitiba, the estimated diseconomies were regarding travel time, fuel consumed on traffic congestions, pollutant emissions, bus operational costs and traffic accidents.

For the cost/benefit analysis, projections on these values were made for the 35 -year horizon so that cash flow could be estimated over this period (which is the minimum project lifetime).

Table 7 - Costs to implement Curitiba's Subway 1st Stage

\begin{tabular}{|c|c|c|c|}
\hline Items & Description & Total R\$ & \% \\
\hline 01 & Construction Works & $1,269,319,081.95$ & 56.34 \\
\hline 02 & Permanent Way & $83,476,344.12$ & 3.70 \\
\hline 03 & Systems & $387,655,293.52$ & 17.26 \\
\hline 04 & Rolling Stock & $324,000,000.00$ & 14.38 \\
\hline 05 & Other Costs & $90,487,000.00$ & 4.02 \\
\hline Sub total & $\mathbf{2 , 1 5 4 , 9 4 0 , 7 1 9 . 5 9}$ & $\mathbf{9 5 . 7 0}$ \\
\hline Contingencies & $98,000,000.00$ & 4.30 \\
\hline Overall Total & $\mathbf{2 , 2 5 2 , 9 4 0 , 7 1 9 . 5 9}$ & $\mathbf{1 0 0 . 0 0}$ \\
\hline Cost per km & \multicolumn{2}{|c|}{$176,010,993.72$} \\
\hline
\end{tabular}

Source: Own elaboration from CBTU's data (2009), updated based on IGPM for 2017 


\subsection{Computing Time Gain}

Work-based travels have productive value for the employees and society. In order to estimate their time value, it is used a model based on salary per time period (usually per hour) or based on wage rate plus the additional costs for the employer.

In Brazil, these additional costs are calculated based on social taxes, which are approximately $62 \%$ of the employee's salary. Considering that, the economic values of financial wages were calculated, and that reflects some labor market distortions. Subsequently, the shadow price rates for the salary-per-hour rates were estimated based on their weighted averages (collected in the demand study) plus the employer's additional costs.

\subsection{Computing Pollution Reduction}

To estimate pollution cost, the methodology and costs adopted on the World Bank's Low Carbon Study (2010) were considered. The valuation of the benefits of "reducing pollution costs" was, then, obtained based on the basic values adopted on IPEA and ANTP's Urban Diseconomies Reduction from Public Transport Improvement Study, as of August 1998. Then, some updates were made, considering the emission parameters obtained by CETESB (2009) for the São Paulo Metropolitan Area. The calculated values are presented in Table 9.

\subsection{Computing Accidents' Cost}

The World Bank's methodology used on its feasibility studies for funding was also adopted for estimating the costs of accidents. The unit cost information for bus public transport systems were obtained from studies carried out by the World Bank in Brazil - particularly from CBTU's Decentralization Programs for the urban rail systems of Rio de Janeiro, São Paulo, Belo Horizonte and Recife, and from the Low Carbon Study for Brazil report (2010). The calculated values for accident reduction will be presented in Table 9.

\subsection{Computing Operational Costs and Fuel Consumption}

Operational and fuel consumption costs were estimated based on the forecast subway demand and the mileage traveled by the buses that would no longer circulate on the streets (due to the project's implementation), multiplied by the bus operational cost. This value involves the economy resulting from reducing diesel consumption, among others. The calculated values of these costs can be observed in Table 9.

\subsection{Computing Savings in Petroleum Barrels}

In order to determine the savings in petroleum barrels arising from Curitiba's subway implementation, the mileage that buses would no longer travel due to the BRT system's replacement by the subway was considered. This mileage was then multiplied by the buses' consumption coefficient; that is, 0.850 1/km (Calculating Urban Bus Fares - GEIPOT, 1996).

Afterwards, a volume of 1,546,648,176 liters of diesel was estimated for the case of Curitiba. Therefore, the amount saved was calculated based on the price of diesel at fuel pumps, which was $\mathrm{R} \$ 2.894$ (ANP, 2017) in Curitiba, thus reaching value of $\mathrm{R} \$ 4,475,999,821$ in savings for the 35-year horizon.

Finally, Table 8 below presents information used in order to estimate the economy in terms of petroleum barrels. In this table, there is information on petroleum volume percentage converted on each derivative. 
Table 8 - Extraction Percentage of Derivatives from Petrol Refine in the Brazilian Consumer Market

\begin{tabular}{|c|c|}
\hline \multicolumn{2}{|c|}{ Division on oil refining (\% volume) } \\
\hline LPG & 8.1 \\
\hline Naphtha & 10.5 \\
\hline Gasoline & 19.5 \\
\hline Kerosene & 2.6 \\
\hline Diesel & 36.4 \\
\hline Others & 22.9 \\
\hline
\end{tabular}

Source: Schaeffer et al., (2004 apud TAVARES, 2005)

Considering that over 35 years approximately 1,546,648,176 liters of diesel fuel will be saved (and converting this amount into petroleum barrels) a number of 9,172,951 units is obtained. By multiplying this quantity by the barrel's market value (US\$ $32.72-2017$, ANP) and by the average dollar exchange rate ( $\mathrm{R} \$ 3.20$ in 2017), the projected economy was of $\mathrm{R} \$ 1,172,391,982$, which corresponds to $33 \%$ of the estimated value of the first stage of Curitiba's subway implementation.

\subsection{Results Analysis of the Socioeconomic Evaluation}

This section presents the results of the socioeconomic analysis. Table 9 shows the socioeconomic cash flow of Curitiba's project over its lifetime, which is considered to be 35 years for subway projects.

Table 9 - Socioeconomic Cash Flow - Curitiba's Subway Project (R\$ x 1,000,000)

\begin{tabular}{|c|c|c|c|c|c|c|c|c|c|c|}
\hline \multicolumn{3}{|c|}{ Direct Benefits } & \multicolumn{2}{|c|}{ Externalities } & \multirow[b]{2}{*}{$\begin{array}{c}\text { Total } \\
\text { Benefit } \\
\text { s }\end{array}$} & \multicolumn{4}{|c|}{ Operational Costs } & \multirow[b]{2}{*}{$\begin{array}{c}\text { Benefit } \\
\text { s minus } \\
\text { Costs }\end{array}$} \\
\hline $\begin{array}{l}\text { Time } \\
\text { Saving }\end{array}$ & $\begin{array}{c}\text { Bus } \\
\text { Operatio } \\
\text { nal Cost }\end{array}$ & $\begin{array}{c}\text { System's } \\
\text { Manage } \\
\text { ment } \\
\text { Cost }\end{array}$ & $\begin{array}{l}\text { Accid } \\
\text { ents } \\
\text { Costs }\end{array}$ & $\begin{array}{c}\text { Pollution } \\
\text { Costs }\end{array}$ & & $\begin{array}{c}\text { Invest } \\
\text { ment }\end{array}$ & $\begin{array}{l}\text { Total } \\
\text { Cost }\end{array}$ & $\begin{array}{c}\text { Cost } \\
\text { with } \\
\text { Project }\end{array}$ & $\begin{array}{c}\text { Differe } \\
\text { ntial } \\
\text { Costs }\end{array}$ & \\
\hline 0 & 0 & 0 & 0 & 0 & 0 & 250.7 & 0 & 0 & 0 & -250.7 \\
\hline 0 & 0 & 0 & 0 & 0 & 0 & 448.1 & 0 & 0 & 0 & -448.1 \\
\hline 0 & 0 & 0 & 0 & 0 & 0 & 630.7 & 0 & 0 & 0 & -630.7 \\
\hline 0 & 0 & 0 & 0 & 0 & 0 & 938.4 & 0 & 0 & 0 & -938.3 \\
\hline 0 & 0 & 0 & 0 & 0 & 0 & 752.3 & 0 & 0 & 0 & -752.3 \\
\hline 191.5 & 78.9 & 2.4 & 4.3 & 7.3 & 284.5 & & 48.8 & 100.7 & 51.9 & 232.6 \\
\hline 239.4 & 86.5 & 2.6 & 5.4 & 9.1 & 343.0 & & 48.8 & 102.9 & 54.1 & 288.9 \\
\hline 281.5 & 93.1 & 2.8 & 6.4 & 10.7 & 394.5 & & 48.8 & 105.1 & 56.3 & 338.2 \\
\hline 309.9 & 97.6 & 2.9 & 7.0 & 11.8 & 429.3 & & 48.8 & 107.3 & 58.6 & 370.8 \\
\hline 327.9 & 100.4 & 3.0 & 7.4 & 12.5 & 451.2 & & 48.8 & 109.6 & 60.8 & 390.4 \\
\hline 340.2 & 102.3 & 3.1 & 7.7 & 12.8 & 466.2 & & 48.8 & 111.8 & 63.0 & 403.2 \\
\hline 346.5 & 103.3 & 3.1 & 7.8 & 13.1 & 473.9 & & 48.8 & 114.0 & 65.3 & 408.7 \\
\hline 352.8 & 104.3 & 3.1 & 8.0 & 13.4 & 481.7 & & 48.8 & 115.9 & 67.1 & 414.6 \\
\hline 359.2 & 105.3 & 3.1 & 8.2 & 13.6 & 489.4 & & 48.8 & 117.8 & 69.0 & 420.4 \\
\hline 365.6 & 106.4 & 3.2 & 8.3 & 13.9 & 497.3 & & 48.8 & 117.8 & 69.0 & 428.3 \\
\hline 372.1 & 107.4 & 3.2 & 8.4 & 14.2 & 505.4 & & 48.8 & 117.8 & 69.0 & 436.4 \\
\hline 378.8 & 108.4 & 3.3 & 8.6 & 14.4 & 513.5 & & 48.8 & 117.8 & 69.0 & 444.4 \\
\hline 385.4 & 109.5 & 3.3 & 8.7 & 14.6 & 521.5 & & 48.8 & 117.8 & 69.0 & 452.5 \\
\hline 392.2 & 110.5 & 3.3 & 8.9 & 14.8 & 529.2 & & 48.8 & 117.8 & 69.0 & 460.7 \\
\hline 398.9 & 111.6 & 3.4 & 9.0 & 15.2 & 538.3 & & 48.8 & 117.8 & 69.0 & 469.1 \\
\hline 405.8 & 112.7 & 3.4 & 9.2 & 15.4 & 546.5 & & 48.8 & 117.8 & 69.0 & 477.5 \\
\hline 412.7 & 113.8 & 3.4 & 9.4 & 15.7 & 554.9 & & 48.8 & 117.8 & 69.0 & 486.0 \\
\hline 419.8 & 114.9 & 3.4 & 9.5 & 15.9 & 563.6 & & 48.8 & 117.8 & 69.0 & 494.5 \\
\hline 426.8 & 115.9 & 3.5 & 9.7 & 16.2 & 572.2 & & 48.8 & 117.8 & 69.0 & 503.2 \\
\hline 433.9 & 117.1 & 3.5 & 9.8 & 16.5 & 580.9 & & 48.8 & 117.8 & 69.0 & 511.9 \\
\hline 441.2 & 118.2 & 3.5 & 10.0 & 16.8 & 589.8 & & 48.8 & 117.8 & 69.0 & 520.73 \\
\hline 441.2 & 118.2 & 3.5 & 10.0 & 16.8 & 589.8 & & 48.8 & 117.8 & 69.0 & 520.73 \\
\hline
\end{tabular}




\begin{tabular}{|c|c|c|c|c|c|c|c|c|c|c|}
\hline \multicolumn{3}{|c|}{ Direct Benefits } & \multicolumn{2}{|c|}{ Externalities } & \multirow[b]{2}{*}{$\begin{array}{c}\text { Total } \\
\text { Benefit } \\
\text { s }\end{array}$} & \multicolumn{4}{|c|}{ Operational Costs } & \multirow[b]{2}{*}{$\begin{array}{c}\text { Benefit } \\
\text { s minus } \\
\text { Costs }\end{array}$} \\
\hline $\begin{array}{l}\text { Time } \\
\text { Saving }\end{array}$ & $\begin{array}{c}\text { Bus } \\
\text { Operatio } \\
\text { nal Cost }\end{array}$ & $\begin{array}{c}\text { System's } \\
\text { Manage } \\
\text { ment } \\
\text { Cost }\end{array}$ & $\begin{array}{l}\text { Accid } \\
\text { ents } \\
\text { Costs }\end{array}$ & $\begin{array}{c}\text { Pollution } \\
\text { Costs }\end{array}$ & & $\begin{array}{c}\text { Invest } \\
\text { ment }\end{array}$ & $\begin{array}{l}\text { Total } \\
\text { Cost }\end{array}$ & $\begin{array}{c}\text { Cost } \\
\text { with } \\
\text { Project }\end{array}$ & $\begin{array}{c}\text { Differe } \\
\text { ntial } \\
\text { Costs }\end{array}$ & \\
\hline 441.2 & 118.2 & 3.5 & 10.0 & 16.8 & 589.8 & & 48.8 & 117.8 & 69.0 & 520.73 \\
\hline 441.2 & 118.2 & 3.5 & 10.0 & 16.8 & 589.8 & & 48.8 & 117.8 & 69.0 & 520.73 \\
\hline 441.2 & 118.2 & 3.5 & 10.0 & 16.8 & 589.8 & & 48.8 & 117.8 & 69.0 & 520.73 \\
\hline 441.2 & 118.2 & 3.5 & 10.0 & 16.8 & 589.8 & & 48.8 & 117.8 & 69.0 & 520.73 \\
\hline 441.2 & 118.2 & 3.5 & 10.0 & 16.8 & 589.8 & & 48.8 & 117.8 & 69.0 & 520.73 \\
\hline 441.2 & 118.2 & 3.5 & 10.0 & 16.8 & 589.8 & & 48.8 & 117.8 & 69.0 & 520.73 \\
\hline 441.2 & 118.2 & 3.5 & 10.0 & 16.8 & 589.8 & & 48.8 & 117.8 & 69.0 & 520.73 \\
\hline 441.2 & 118.2 & 3.5 & 10.0 & 16.8 & 589.8 & & 48.8 & 117.8 & 69.0 & 520.73 \\
\hline 441.2 & 118.2 & 3.5 & 10.0 & 16.8 & 589.8 & & 48.8 & 117.8 & 69.0 & 520.73 \\
\hline 441.2 & 118.2 & 3.5 & 10.0 & 16.8 & 589.8 & & 48.8 & 117.8 & 69.0 & 520.73 \\
\hline 441.2 & 118.2 & 3.5 & 10.0 & 16.8 & 589.8 & & 48.8 & 117.8 & 69.0 & 520.73 \\
\hline 441.2 & 118.2 & 3.5 & 10.0 & 16.8 & 589.8 & & 48.8 & 117.8 & 69.0 & 520.73 \\
\hline 441.2 & 118.2 & 3.5 & 10.0 & 16.8 & 589.8 & & 48.8 & 117.8 & 69.0 & 520.73 \\
\hline 441.2 & 118.2 & 3.5 & 10.0 & 16.8 & 589.8 & & 48.8 & 117.8 & 69.0 & 520.73 \\
\hline
\end{tabular}

Source: Made by the authors

The cash flow results are presented in Table 10 below. A $6.5 \%$ tax per year was used for estimating the payback with deductions.

Table 10 - Cash Flow Results

\begin{tabular}{|c|c|}
\hline Net Present Value & $\mathbf{1 , 8 1 3 , 6 5 3}$ \\
Internal Rate of Return & $\mathbf{1 0 . 6 \%}$ \\
Net Present Value (Benefit) & $\mathbf{4 , 8 8 3 , 3 7 6}$ \\
Net Present Value (Costs) & $\mathbf{3 , 7 1 9 , 1 9 2}$ \\
Benefit/Cost Ratio & $\mathbf{1 . 3 1}$ \\
Payback (classic) & $\mathbf{1 2}$ YEARS \\
Payback (deducting 6.5\% inflation rate) & $\mathbf{2 3}$ YEARS \\
\hline
\end{tabular}

Source: Made by the authors based on the results of the socioeconomic analysis

The tables above present information that enables the following conclusions:

- Time saving - the travel time considering the subway's implementation will be reduced from 50 to 25 minutes;

- Operational costs (fuel and management) - due to technology replacement, the annual economy will be around R 118 million per year at the end of the project lifetime;

- Pollutant emissions - the analysis focused on 4 main pollutants: CO (carbon monoxide), HC (hydrocarbons), NOx (nitrogen oxide) and PM (particulate matter). The annual economy will be of approximately R $\$ 16$ million;

- The socioeconomic analysis for Curitiba's subway project, presented in Table 10, results on an annual internal rate of socioeconomic return of about $10.6 \%$, especially due to the huge benefits obtained by introducing a fast, non-pollutant and safe high capacity system. The socioeconomic net present value is approximately $\mathrm{R} \$ 1,813$ million and the benefit/cost ratio, $\mathrm{R} \$ 1.31$; that is, for each $\mathrm{R} \$ 1.00$ invested on the project, $\mathrm{R} \$ 1.31$ returns as social benefits. 


\section{CONCLUSIONS}

The analyses of the results of the socioeconomic evaluation show that the benefits from the subway's implementation would result in great gains for the population of Curitiba.

In order to evaluate fossil fuel savings (non-renewable energy) a specific analysis about diesel oil consumption economy due to the subway's implementation was carried out, considering that Brazil is still not self-sufficient in light oil production or with regard to refinery capacity of diesel fuel. Besides, even if it were self-sufficient, diesel consumption economy would make more petroleum barrels available for exportation purposes.

The analysis of the available data shows that switching from bus to subway technology, 1.55 million liters of diesel would be saved over the project lifetime. Furthermore, by not consuming diesel, it would no longer be necessary to import raw material, which implies in reduction of imported petroleum of 1.5 million barrels over the project lifetime. Taking into account the barrel price (ANP - US\$ 37.72 average value in 2017), this economy would represent US\$ 3,66 million, which, considering a $\mathrm{R} \$ 3.20$ dollar exchange rate, means $\mathrm{R} \$ 1,172$ billion, 33\% of Curitiba's subway first stage costs.

It is also worth emphasizing the benefits concerning accidents and pollutant costs due to their peculiarity. The estimated costs related to accidents are very subjective as it is difficult to quantify the value of a lost life or physical damages caused. In this case, the monetary values associated to life insurance premiums were adopted for the calculation, even knowing this is a limited reasoning. Moreover, it must be noticed that this externality cost varies from country to country and is considered very controversial.

On the other hand, concerning pollutant emission costs, due to the lack of specific studies on Brazilian conditions, European and North-American data were used, and were reduced according to the approximate ratio between Brazilian and North-American per capita income.

It is relevant to mention that the present work analyzed diesel oil economy only, not considering gasoline and ethanol consumption savings due to the passengers that would no longer use cars as their main transportation mode, since they would start using the subway.

The main limitation affecting this study was the lack of an equation that could turn this economy (or at least part of it) into subway-railway system funding, although a significant diesel fuel economy (and consequently petroleum economy) would arise.

As examples of limitations for studies on this matter, one should consider the difficulties to obtain consistent data, since it is many times considered confidential for government institutions such as ANP and PETROBRÁS, among others.

A recommendation for future works is to conduct a study considering the economy of all fuel types (including gasoline, ethanol and bio-diesel, for example) and not only diesel oil. It would also be relevant to find out a legal way to make it possible to convert fossil fuel economy into funding for railway system infrastructure.

Finally, another recommendation is to evaluate the gains resulting from land market price valorization on the subway line surroundings and the possible increase on IPTU tax collection, aiming at project funding. On this work, this issue was not taken into account as the corridor on which the subway will be implemented was already object of urban transactions (land sale) along the BRT edge. Property valorization is not considered an externality in socioeconomic analysis because it is indirectly embedded in users' travel time economy, and this evaluation is always made from the user's point-of-view as demand is the main input. However, for studies on tax increase or to calculate created land, it is essential to consider property valorization. 


\section{BIBLIOGRAPHIC REFERENCES}

AGÊNCIA NACIONAL DE ENERGIA ELÉTRICA. ANNEL. Atlas da Energia Elétrica no Brasil - Energia no Brasil e no Mundo - consumo. 2008.. Disponível em: < http://www2.aneel.gov.br/arquivos/pdf/atlas3ed.pdf >. Acesso em: 06 set. 2016.

AGÊNCIA NACIONAL DO PETRÓLEO, GÁS NATURAL E BIOCOMBUSTÍVEIS. ANP. Informações sobre preço do barril de petróleo em 2011. Anuário da ANP 2010. Disponível em: < http://www.anp.gov.br/wwwanp/publicacoes/anuario-estatistico/2435-anuario-estatistico-2010>. Acesso em: 04 fev. 2017.

ALJOUFIE, M., BRUSSEL, M., Zuidgeest, M., VAN DELDEN, H., \& Van Maarseveen, M. Integrated analysis of land-use and transport policy interventions. Transportation Planning and Technology, v.39, n.4, p.329-357, 2016

ARAGÃO, Joaquim José Guilherme; YAMASHITA, Yaeko; ORRICO FILHO, Romulo Dante. BRT in Brazil: Designing services in function of given infrastructure projects or designing infrastructure in function of established service quality patterns?. Research in Transportation Economics, v. 59, p. 304-312, 2016

ASSOCIAÇÃO NACIONAL DAS EMPRESAS DE TRANSPORTES URBANOS. NTU. Avaliação comparativa das modalidades de transporte público urbano. 2009. Disponível em: < http://www.ntu.org.br/novo/upload/Publicacao/Pub635109537433018893.pdf.> Acesso em: 10 jan. 2017.

ASSOCIAÇÃO NACIONAL DE TRANSPORTE PÚBLICO. ANTP. Mobilidade Humana para um Brasil Urbano. São Paulo 2017. p. 13-37.

ASSOCIAÇÃO NACIONAL DE TRANSPORTE PÚBLICO. ANTP. Sistema de Informações da Mobilidade. Disponível em: < http://www.antp.org.br/sistema-de-informacoes-da-mobilidade/apresentacao.html >. Acesso em: 05 fev. 2017.

BANCO MUNDIAL. Estudo de Baixo Carbono para o Brasil - Relatório Síntese Técnica - Transportes. 2010. Disponível em: < http://siteresources.worldbank.org/BRAZILINPOREXTN/Resources/38171661276778791019/Relatorio_BM_Principal_Portugues_SumarioExecutivo.pdf/> Acesso em: 05 fev.2017.

BANCO MUNDIAL. World Bank (Staff Appraisal Report). Belo Horizonte Metropolitan Transport Descentralization Project e Recife Metropolitan Transport Descentralization Project. 1995. Disponível em: < http://documents.worldbank.org/curated/pt/774341468020698401/Brazil-Recife-Metropolitan-Transport-

Decentralization-Project-and-Belo-Horizonte-Metropolitan-Transport-Project> Acesso em: 10 fev. 2016.

BERTOLINI, L.;SPIT, T. .Cities on rails: the redevelopment of railway areas. Londres. Milton Keynes 2007.

BRANDÃO, L. M. Medidores eletrônicos de velocidade: uma visão da engenharia para a implantação. Curitiba: Perkons, 2006. 150 p.

BRASIL. MINISTÉRIO DA CIÊNCIA, TECNOLOGIA, INOVAÇÃO E COMUNICAÇÃO. Estimativas Anuais de Emissões de Gases de Efeito Estufa no Brasil - 2012. Brasília, 2014. Disponível em: < http://sirene.mcti.gov.br/documents/1686653/1706227/Estimativas+2ed.pdf/0abe2683-e0a8-4563-b2cb-4c5cc536c336 $>$ Acesso em: 10 dez. 2016.

BRASIL. MINISTÉRIO DAS CIDADES. Manual de BRT - Bus Rapid Transit - Guia de Planejamento (2008). Disponível em: < http://www.cidades.gov.br/images/stories/ArquivosSEMOB/Biblioteca/ManualBRT.pdf >. Acesso em: 12 dez.2016.

BRASIL. MINISTÉRIO DE MINAS E ENERGIAS. Disponível em: < www.mme.gov.br>. Acesso em: 10 jul. 2017.

BRASIL. MINISTÉRIO DO MEIO AMBIENTE. Inventário Nacional de Emissões Atmosféricas por Veículos Automotores Rodoviários 2013, Ano-Base 2012. Brasília, 2013. Disponível em: <http:// http://www.mma.gov.br/images/arquivo/80060/Inventario_de_Emissoes_por_Veiculos_Rodoviarios_2013.pdf> Acesso em: 12 dez. 2016.

BRASIL. MINISTÉRIO DOS TRANSPORTES. Cálculo de Tarifas de Ônibus Urbanos. Instruções Práticas Atualizadas. 2a. Brasília : GEIPOT, 1996.

COMPANHIA AMBIENTAL DO ESTADO DE SÃO PAULO. CETESB. Qualidade do Ar no Estado de São Paulo 2009. 2010. Disponível em: <http://sistemasinter.cetesb.sp.gov.br/Ar/publicacoes.asp >. Acesso em: 10 fev. 2017. 
COMPANHIA BRASILEIRA DE TRENS URBANOS. CBTU. Disponível em: < http://www.cbtu.gov.br/index.php/pt/desempenho/relatorio-mensal-de-atividades>. Acesso em: 5 jan. 2017.

DARGAY, J.; GATELY, D. The demand for transportation fuels: Imperfect pricereversibility? Transportation Research, vol. 1, n. 4, p. 357-386, 2007.

DIAS, R.A.; BALESTIERI, J.A.P.; MATTOS, C.R. Um Exercício de Uso Racional da Energia: O Caso do Transporte Coletivo. 2006. Disponível em:< https://periodicos.ufsc.br/index.php/fisica/article/view/6288> Acesso em: 05 mai. 2016.

FERRAZ, A. C. P.; RAIA JR., A. A.; BEZERRA, B. S. Segurança no trânsito. São Carlos: Nest, 2008. 280 p.

GELLER, Howard S. Revolução Energética: políticas para um futuro sustentável. Trad. Maria Vidal Barbosa. Relume Dumará, Rio de Janeiro, 2003.

GOMIDE, A. Transporte Urbano e Inclusão Social: Elementos para Políticas Públicas. IPEA. Brasília, 2003. (Texto para discussão, n. 960)

GUARIERO, L. L. N.;VASCONCELlOS, P. C.; SOLCI, M. C. Poluentes Atmosféricos Provenientes da Queima de Combustíveis Fósseis e Biocombustíveis: Uma Breve Revisão. Rev. Virtual Quim., 2011, 3 . Disponível em: <http://www.uff.br/rvq> Acesso em: 27 jun. 2017.

INSTITUTO DE PESQUISA E PLANEJAMENTO URBANO DE CURITIBA. IPPUC. Disponível em: < http://curitibaemdados.ippuc.org.br/Curitiba_em_dados_Pesquisa.htm>. Acesso em: 12 nov. 2016

INSTITUTO DE PESQUISA ECONÔMICA APLICADA. IPEA e ASSOCIAÇÃO NACIONAL DE TRANSPORTE PÚBLICO. ANTP. Redução das deseconomias urbanas com a melhoria do transporte público. Relatório final. Brasília, 1998. Disponível em: < http://www.ipea.gov.br/agencia/images/stories/PDFs/TDs/td_0586.pdf >. Acesso em: 13 abr.2016.

INSTITUTO DE POLITICAS DE TRANSPORTE E DESENVOLVIMENTO. ITDP. Manual de BRT - Guia de Planejamento. 2009. Disponível em: < http://itdpbrasil.org.br/manual-de-brt-guia-de-planejamento/>. Acesso em: 18 dez. 2016.

INTERNATIONAL ENERGY AGENCY. IEA. World energy statistics From the IEA 2008. Disponível em: < https://www.iea.org/media/weowebsite/2008-1994/WEO2008.pdf > Acesso em: 02 set.2016.

LA CONVECION MARCO DE LAS NACIONES SOBRE EL CAMBIO CLIMATICO. CQNUMC - Convenção Quadro das Nações Unidas para a Mudança do Clima (2004). Documento de Concepção de Projeto BRT Bogotá, Colombia: TransMilenio Phase II to IV. Disponível em: < https://cdm.unfccc.int/Projects/DB/DNVCUK1159192623.07/view?cp=1 > Acesso em: 10 abr. 2017.

LANDMANN, M.C.; RIBEIRO, H.; DEÁK, C; Uma proposta metodológica para estimar o custo da poluição do ar nas análises de viabilidade de sistemas de transportes urbanos. TRANSPORTES, volume XV, número 1 , junho de 2007. ISSN: 1415-7713.

LEITE, A. D. A energia do Brasil. Rio de Janeiro: Nova Fronteira, 1997. 528 p.

LIN, Boqiang; BENJAMIN, Nelson I. Influencing factors on carbon emissions in China transport industry. A new evidence from quantile regression analysis. Journal of Cleaner Production, v. 150, p. 175-187, 2017

Manual Operacional. Avaliação de Projetos de Transportes Urbanos. V.1. Empresas Brasileiras dos Transportes Urbanos - EBTU. Brasília. 1987.

MARINS, K.R. C. C.; ROMÉRO, M. A.. Avaliação do potencial da integração de condicionantes de mobilidade urbana no planejamento energético de áreas urbanas. Revista ANTP, n. 130 p.9-24, 2012.

MATTOS, T, M. Análise de Projetos de Redução de Emissão de Gases do Efeito Estufa no Setor de Transportes Estudo de Caso dos BRTS no Rio de Janeiro. Rio de Janeiro: UFRJ / Escola politécnica, 2011.

ONU-HABITAT (Programa de las Naciones Unidas para los Asentamientos Humanos). Planificación y diseño de una movilidad urbana sostenible: Orientaciones para políticas: Informe mundial sobre asentamientos humanos 2013 .Resumen Ejecutivo. Nova Iorque: ONU-Habitat/Routledge. Disponivel em: $<$ http://mirror.unhabitat.org/pmss/listItemDetails. aspx?publicationID=3501 > Acesso em: 10 mar. 2017.

PAGET-SEEKINS, Laurel; WALTERS, Jackie. Workshop 6 report: Reassessing public operations. Research in Transportation Economics, v. 59, p. 277-280, 2016. 
PINHEIRO, A. C.; FONTES, J.; AZEVEDO, L. . Crise da mobilidade urbana no Brasil: custos econômicos e soluções. In: PINHEIRO, Armando Castelar et al. (Org.). Mobilidade Urbana: Desafios e Perspectivas para as Cidades Brasileiras. Rio de Janeiro: ELSEVIER, 2015. cap. 2, p. 37-74.

RIBEIRO, H.; ASSUNÇÃO, J. V. Historical overview of air pollution in São Paulo metropolitan area, Brazil: influence of mobile sources and related health effects. In: Urban Transport and Environment for the 21st Century III, ed. L. Sucharov and A. Brebbia. Publischer: Computational Mechanics Publication, Southampton, UK.351-60, 2001.

RIBEIRO, S., K., (org.) Barreiras na Implantação de Alternativas Energéticas para o Transporte Rodoviário no Brasil, Centro de Estudos Integrados Sobre Meio Ambiente e Mudanças Climáticas - Centro Clima - COPPE/UFRJ, Rio de Janeiro. 2002.

SCHAEFFER, R; SZKLO, A; MACHADO, M.; MARIANO, J.; SALA, J.; TAVARES. M.; MAGRINI, A . 2004. Evolução do Mercado Brasileiro de Derivados de Petróleo e Perspectivas de Expansão do Parque de Refino Nacional até 2015. Projeto de pesquisa executado para o IBP. PPE/COPPE/UFRJ. Rio de Janeiro.

SILVA, A. H. Determinação da área de captação de uma estação de metrô por meio da utilização do modelo prisma espaço-tempo e padrão de viagens. Dissertação de Mestrado, Publicação T. DM-003A/2008, Departamento de Engenharia Civil e Ambiental, Universidade de Brasília. 2008.

SMALL, K. Fundamentals of Economic Demand Modeling: Lessons from Travel Demand Analysis. In Decision Making in Engineering Design, edited by K. Lewis, W. Chen and L Schmidt. New York: ASME Press, 2006.

SMALL, K. Urban Transportation Economics. Harwood Academic Plubishers, 1992.

SOUZA, G. A. Produção do espaço e mobilidade urbana: na contramão da sustentabilidade. Revista Produção e Desenvolvimento, v.1, n.3, p.42-51, 2015. Disponível em: $<\quad$ http://revistas.cefet-rj.br/index. php/producaoedesenvolvimento/article/view/109 > Acesso em: 10 jul. 2017.

TAVARES, M. E. E. Análise do refino no Brasil: estado e perspectivas - uma análise cross-section. 2005. 402p. Tese (Doutorado em Planejamento Energético) - COPPE, Universidade Federal do Rio de Janeiro. 2005.

UN-HABITAT (United Nations Human Settlement Programme). Planning and design for sustainable urban mobility. Global Report on Human Settlements Series. Nova Iorque: UN-Habitat. 2013. Disponível em:< http://bit.ly/2bSWeUD $>$ Acesso em: 10 jul. 2017
URBANIZAÇÃO
DE
CURITIBA
S.
A.
URBS.
Disponível
em:<

https://www.urbs.curitiba.pr.gov.br/transporte/estatisticas> Acesso em: 08 fev. 2017

VASCONCELLOS, E.A.; LIMA, I.M.O. Quantificação das Deseconomias do Transporte Urbano: Uma Resenha das Experiências Internacionais, Brasília, agosto de 1998.

VASCONCELOS, E.A. Transporte urbano nos países em desenvolvimento: Reflexões e Propostas. São Paulo: Annablume, 2000.

VIANNA, G. S. B. A relação entre mobilidade urbana e bem-estar através da abordagem das capacitações. 2016.130 f. Dissertação (Mestrado). Programa de Pós-Graduação em Economia - Universidade Federal Fluminense (UFF), Niterói, Rio de Janeiro, 2016.

VIANNA, G. S. B.; YOUNG, C.E.F. Em busca do tempo perdido: uma estimativa do produto perdido em trânsito no Brasil. Revista de Economia Contemporânea (Impresso), v. 19, n. 3, p. 403-416, 2015.

VIEIRA, C.A.; SILVA, A. F. Aspectos da poluição atmosférica: uma reflexão sobre a qualidade do ar nas cidades brasileiras. publicação em 02/06.2017. Revista Ciência e Sustentabilidade - CeS Juazeiro do Norte, v.3, n. 1, p. 166189, jan/jun 2017. ISSN: 2447-4606

VLT Carioca. Disponível em:< http://vltrio.rio/o-projeto/> Acesso em: 10 jul. 2017.

This work is licensed under a Creative Commons Attribution 4.0 International License. 